\title{
CONTOH PELANGGARAN HAK PATEN ATAS DESAIN FITUR SLIDE TO UNLOCK (STUDI KASUS APPLE VS SAMSUNG)
}

\author{
Febri Yandi \\ 155100030 \\ Fakultas Komputer, 448757155 \\ febriyandi.student@umitra.ac.id
}

\begin{abstract}
Paten adalah hak eksklusif yang diberikan oleh Negara kepada penemu atas hasil penemuannya di bidang teknologi, yang untuk selama waktu tertentu melaksanakan sendiri Invensinya tersebut atau memberikan persetujuannya kepada pihak lain untuk melaksanakannya (UU RI no. 14 tahun 2001, pasal 1, ayat 1).

Pemegang hak paten memiliki hak eklusif untuk melaksanakan Paten yang dimilikinya dan melarang orang lain yang tanpa persetujuannya, Dalam hal Paten Produk: membuat, menjual, mengimpor, menyewa, menyerahkan, memakai, menyediakan untuk di jual atau disewakan atau diserahkan produk yang di beri paten. Menggunakan proses produksi yang diberi Paten untuk membuat barang dan tindakan lainnya sebagaimana yang telah dijelaskan sebelumnya.
\end{abstract}

Yang perlu dihindari sebelum permintaan paten diajukan adalah pengungkapan atau mempublikasikan secara umum hasil penelitian atau penemuan dalam jangka waktu lebih dari 6 (enam) bulan sebelum permintaan paten diajukan.

Kata Kunci : Hak Atas Kekayaan Intelektual (HAKI), Paten, Inventor, Slide-tounlock. 


\section{A. INTRODUCTION}

\section{Defisini Paten}

Paten adalah hak eksklusif yang diberikan oleh Negara kepada penemu atas hasil penemuannya di bidang teknologi, yang untuk selama waktu tertentu melaksanakan sendiri Invensinya tersebut atau memberikan persetujuannya kepada pihak lain untuk melaksanakannya. (UU RI no. 14 tahun 2001, pasal 1, ayat 1)

Kata paten, berasal dari bahasa inggris patent, yang awalnya berasal dari kata patere yang berarti membuka diri (untuk pemeriksaan publik), dan juga berasal dari istilah letters patent, yaitu surat keputusan yang dikeluarkan kerajaan yang memberikan hak eksklusif kepada individu dan pelaku bisnis tertentu. Dari definisi kata paten itu sendiri, konsep paten mendorong inventor untuk membuka pengetahuan demi kemajuan masyarakat dan sebagai gantinya, inventor mendapat hak eksklusif selama periode tertentu. Mengingat pemberian paten tidak mengatur siapa yang harus melakukan invensi yang dipatenkan, sistem paten tidak dianggap sebagai hak monopoli.

\section{Hak yang dimiliki Oleh Pemegang Paten}
Pemegang hak paten memiliki hak eklusif untuk melaksanakan Paten yang dimilikinya dan melarang orang lain yang tanpa persetujuannya :

a. Dalam hal Paten Produk: membuat, menjual, mengimpor, menyewa, menyerahkan, memakai, menyediakan untuk di jual atau disewakan atau diserahkan produk yang di beri paten.

b. Dalam hal Paten Proses: Menggunakan proses produksi yang diberi Paten untuk membuat barang dan tindakan lainnya sebagaimana yang dimaksud dalam huruf a.

- Pemegang Paten berhak memberikan lisensi kepada orang lain berdasarkan surat perjanjian lisensi.

- Pemegang Paten berhak menggugat ganti rugi melalui pengadilan negeri setempat, kepada siapapun, yang dengan sengaja dan tanpa hak melakukan perbuatan sebagaimana dimaksud dalam butir 1 di atas.

- Pemegang Paten berhak menuntut orang yang dengan sengaja dan tanpa hak melanggar 


$$
\begin{aligned}
& \text { hak pemegang paten } \\
& \text { dengan melakukan } \\
& \text { salah satu tindakan } \\
& \text { sebagaimana yang } \\
& \text { dimaksud dalam butir } 1 \\
& \text { di atas. }
\end{aligned}
$$

\section{Defisini Inventor}

Inventor adalah seorang yang secara sendiri atau beberapa orang yang secara bersamasama melaksanakan ide yang dituangkan ke dalam kegiatan yang menghasilkan invensi. Pemegang paten adalah inventor sebagai pemilik paten atau pihak yang menerima hak tersebut dari pemilik paten atau pihak lain yang menerima lebih lanjut hak tersebut, yang terdaftar dalam daftar umum paten.

\section{Hal-hal yang sebaiknya dilakukan oleh seorang Inventor sebelum mengajukan permohonan Paten?}

a. Melakukan penelusuran. Tahapan ini dimaksudkan untuk mendapatkan informasi tentang teknologi terdahulu dalam bidang invensi yang sama (state of the art) yang memungkinkan adanya kaitannya dengan invensi yang akan diajukan. Melalui informasi teknologi terdahulu tersebut maka inventor dapat melihat perbedaan antara invensi yang akan diajukan permohonan Patennya dengan teknologi terdahulu. b. Melakukan Analisis. tahapan ini dimaksudkan untuk menganalisis apakah ada ciri khusus dari invensi yang akan diajukan permohonan Patennya dibandingkan dengan Invensi terdahulu.

c. Mengambil Keputusan. Jika invensi yang dihasilkan tersebut mempunyai ciri teknis dibandingkan dengan teknologi terdahulu, maka invensi tersebut sebaiknya diajukkan permohonan

Patennya.Sebaliknya jika tidak ditemukan ciri khusus, maka invensi tersebut sebaiknya tidak perlu diajukan untuk menghindari kerugian dari biaya pengajuan permohonan Paten.

Ada 2 macam sistem pendaftaran paten, yaitu :

a. Sistem First to File adalah suatu sistem yang memberikan hak paten bagi mereka yang mendaftar pertama atas invensi baru sesuai dengan persyaratan.

b. Sistem First to Invent Adalah suatu sistem yang memberikan hak paten bagi mereka yang menemukan inovasi pertama kali sesuai dengan persyaratan yang telah ditentukan. 


\section{Contoh Pelanggaran Hak Paten Slide to Unlock (Studi Kasus Apple VS Samsung}

Slide to unlock pertama kali diperkenalkan Apple pada Januari 2007 saat peluncuran handphone iPhone perdana, yang sengaja dibuat supaya saat iPhone dimasukkan ke dalam kantong, layar iPhone tidak terpencet secara tidak sengaja.

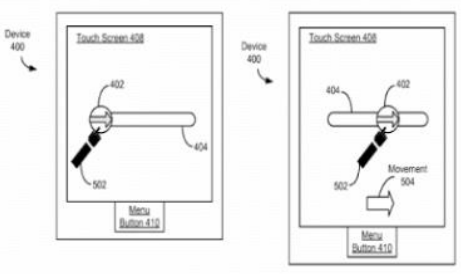

Pimpinan iOS, Scott Forstall diklaim sebagai orang yang menemukan Slide to Unlock, dengan peran serta dari enginer lain seperti Imran Chaudhri, Bas Ording, Freddy Allen Anzures, Marcel Van Os, Stephen O. Lemay and Greg Christie.

Apple telah resmi mendapatkan paten atas desain fitur 'slide to unlock' khas iPhone.

Paten tersebut diberikan U.S. Patent and Trademark Office dan terdaftar dengan nomor D675,639. Dalam deskripsinya, paten ini disebut sebagai 'ornamental design for a display screen or portion thereof with a graphical user interface'.
Selain desain 'slide to unlock', Apple juga mendaftarkan paten bernomor D675,612 dengan deskripsi 'ornamental design of an electronic device', yang isinya menjelaskan mengenai desain sudut membulat yang diusung iPhone.

Apple menuntut Samsung dan akhirnya memenangi hak paten slide-to-

unlock atas Samsung setelah menjalani proses pengadilan selama empat tahun. Dengan kemenangan tersebut, perusahaan besutan Steve Jobs tersebut berhak mendapat royalti US\$ 120 juta atau sekitar Rp 1,6 triliun.

Mahkamah Agung Amerika Serikat menyatakan tidak menerima pengajuan banding atas kasus yang telah diperkarakan sejak 2014 tersebut. Kasus ini memperebutkan hak paten atas slide-to-unlockdan tautan cepat. Samsung dinyatakan telah melanggar kedua hak paten tersebut.

Keputusan tersebut sempat dibatalkan setelah dua tahun ditetapkan, tapi kembali dipulihkan setahun setelahnya. Samsung kemudian mengajukan banding ke Mahkamah Agung dan berakhir dengan kemenangan Apple. 


\section{B. CONCLUSION}

Pelanggaran tentang hak paten merupakan pelanggaran yang cukup serius. Pelanggaran ini biasanya terjadi antara dua perusahaan yang besar dan sudah dikenal oleh masyarakat banyak. Berdasarkan kasus diatas, perusahaan Samsung melanggar peraturan mengenai hak paten terhadap perusahaan Apple. Perusahaan Samsung diharuskan membayar pinalty sebesar US\$ 120 juta atau sekitar $\mathrm{Rp}$ 1,6 triliun terkair pelanggaran Hak Paten Slideto-Unlock yang lebih dulu dipatenkan oleh Apple.

Yang perlu dihindari sebelum permintaan paten diajukan adalah pengungkapan atau mempublikasikan secara umum hasil penelitian atau penemuan dalam jangka waktu lebih dari 6 (enam) bulan sebelum permintaan paten diajukan.

Menurut saya, untuk menghindari gugatan / tuntutan hukum mengenai hak paten, kita juga perlu melakukan penelusuran yang dimaksudkan untuk mendapatkan informasi tentang teknologi dari invensi atau temuan kita apakah mempunyai kesamaan dengan teknlogi - teknologi sebelumnya sehingga dapat terhindar dari plagiarisme.

Kita juga perlu melakukan Analisis mengenai ciri khusus dari invensi atau temuan yang akan kita ajukan permohonan patennya dibandingkan dengan invensi atau temuan terdahulu.

\section{ACKNOWLEDGEMENT} University Of Indonesia University Of Mitra Indonesia Telkom University University Of Mellbourne Saitama University 
D. REFERENCE(Based ISO 690 )

[1] A. S. Putra And O. M. Febriani, "Knowledge Management Online Application In Pdam Lampung Province," In Prosiding International Conference On Information Technology And Business (Icitb), 2018, Pp. 181-187.

[2] A. S. Putra, O. M. Febriani, And B. Bachry, "Implementasi Genetic Fuzzy System Untuk Mengidentifikasi Hasil Curian Kendaraan Bermotor Di Polda Lampung," J. Sist. Inf. Dan Manaj. Basis Data, Vol. 1, No. 1, Pp. 21-30, 2018.

[3] O. M. Febriani And A. S. Putra, "Sistem Informasi Monitoring Inventori Barang Pada Balai Riset Standardisasi Industri Bandar Lampung," J. Inform., Vol. 13, No. 1, Pp. 90-98, 2014.

[4] Putra, Arie Setya. "2018 Artikel Struktur Data, Audit Dan Jaringan Komputer." (2018).

[5] Putra, A. S. (2018, July 17). Paperplain Fundamental Create Application With Borland Delphi 7.0 University Of Mitra Indonesia. Retrieved From Osf.Io/Pbrn9.

\section{E. REFERENCE (Based APA )}

Putra, A. S., Aryanti, D. R., \& Hartati, I. (2018, November). Metode SAW (Simple Additive Weighting) sebagai Sistem Pendukung Keputusan Guru Berprestasi (Studi Kasus: SMK Global Surya). In Prosiding Seminar Nasional Darmajaya (Vol. 1, No. 1, pp. 85-97).

Sari, D. P., Febriani, O. M., \& Putra, A. S. (2018, November). Perancangan Sistem Informasi SDM Berprestasi pada SD Global Surya. In Prosiding Seminar Nasional Darmajaya (Vol. 1, No. 1, pp. 289-294).

Putra, A. S. (2018). Paperplain: Execution Fundamental Create Application With Borland Delphi 7.0 University Of Mitra Indonesia.

Putra, A. S., Sukri, H., \& Zuhri, K. Sistem Monitoring Realtime Jaringan Irigasi Desa (JIDES) Dengan Konsep Jaringan Sensor Nirkabel. IJEIS (Indonesian Journal of Electronics and Instrumentation Systems), 8(2), 221-232.

Darmawan, A., Yuliawati, D., Marcella, O., \& Firmandala, R. (2016). Sistem Absensi dan Pelaporan Berbasis Fingerprint dan SMS Gateway. EXPLORE, $7(1)$. 
Febriani, O. M., Wahyuni, T., \& Yusuf, S. (2017). DESIGN OF WEBSITE-BASED INFORMATION SYSTEM FOR EDOCUMENT ADMINISTRASI IN THE COMMUNITY SERVICE UNIT (A Case Study at Rajabasa District). INTERNATIONAL JOURNAL OF COMPUTERS \& TECHNOLOGY, 16(7), 70107020 .

Febriani, O. M., \& Wahyuni, T. (2017, October). PERANCANGAN SISTEM EDOCUMENT

ADMINISTRASI LOGBOOK PENELITIAN PADA UNIT LAYANAN DI BANDAR LAMPUNG. In Prosiding Seminar Nasional Darmajaya (Vol. 1, No. 1, pp. 187-194).

Febriani, O. M., \& Permadi, A. B. (2017). Implementasi Sistem Aplikasi Data Bimbingan dan Pelanggaran Siswa pada Sekolah Menengah Atas di Lampung Tengah dengan Metode Analisis dan Desain Sistem Terdistribusi (SSAD). EXPERT, 7(1).

Febriani, O. M., \& Ambarwati, L. (2015). PERANCANGAN APLIKASI PENGOLAHAN DATA PENJUALAN UKM KELANTING KHAS TELO DESA SIDOHARJO KECAMATAN JATI AGUNG KABUPATEN LAMPUNG SELATAN. Jurnal Teknologi Informasi dan Bisnis
Pengabdian Masyarakat

Darmajaya, 1(1), 77-95.

Febriani, O. M. (2015). Rancang Bangun Aplikasi Ecommercemenggunakan

Freewebstore pada UKM Kelanting di Desa Sidoharjo Lampung Selatan. Prosiding Sembistek 2014, 1(02), 446458. 